Jemmy J. Pietersz, Karakteristik Surat Tilang....................

Jurnal Sasi Vol. 16 No. 3 Bulan Juli-September 2010

\title{
KARAKTERISTIK SURAT TILANG DALAM PENINDAKAN PELANGGARAN LALU LINTAS DAN ANGKUTAN JALAN
}

Oleh: J. J. Pietersz

\begin{abstract}
Violations action in the field of Traffic and Transportation is the act of sanctioning violations. This action is done by issuing Surat Tilang as a result of the violations found in the inspection of motor vehicles on the road.

Surat Tilang has characterized as a unilateral administrative action as a form of administrative sanctions against violations committed and does not require the court rulings against government actions that are unilateral. Thus, the Surat Tilang is categorized as an Administrative Decision.
\end{abstract}

Key Word: Surat Tilang, Characteristics of Administrative Law.

\section{A. LATAR BELAKANG.}

Sebagai negara yang berdasarkan atas hukum dalam mencapai tujuan kehidupan berbangsa dan bernegara terutama pencapaian kesejahteraan masyarakat dalam pembangunan sebagai amanat Pembukaan Undang-Undang Dasar Negara Republik Indonesia Tahun 1945, sistem lalu lintas dan angkutan jalan memiliki peran strategis sebagai sarana memperlancar arus transportasi barang dan jasa. Lalu lintas dan Angkutan Jalan (selanjutnya disingkat LLAJ) harus dikembangkan potensi dan perannya untuk mewujudkan keamanan, kesejahteraan, ketertiban berlalu lintas dan angkutan jalan dalam rangka mendukung pembangunan ekonomi dan pengembangan ilmu pengetahuan dan teknologi, otonomi daerah, serta akuntabilitas penyelenggaraan negara.

Penyelenggaraan LLAJ didasarkan pada Undang-Undang Nomor 22 Tahun 2009 tentang Lalu Lintas dan Angkutan Jalan - Lembaran Negara Republik Indonesia Tahun 2009 Nomor 96, Tambahan Lembaran Negara Republik Indonesia Nomor 5025 (selanjutnya disebut UndangUndang Nomor 22 Tahun 2009). Dalam
Undang-Undang Nomor 22 Tahun 2009, LLAJ adalah satu kesatuan sistem yang terdiri atas Lalu Lintas, Angkutan Jalan, Jaringan Lalu Lintas dan Angkutan Jalan, Prasarana Lalu Lintas dan Angkutan Jalan, Kendaraan, Pengemudi, Pengguna Jalan, serta pengelolaannya (Pasal 1 angka 1). Terkait dengan LLAJ sebagai satu kesatuan sistem, maka pengelolaan di bidang LLAJ merupakan pengelolaan yang bersifat koordinasi dan integrasi yang dilaksanakan secara bersama-sama oleh beberapa instansi terkait.

Penegakan hukum berupa penindakan terhadap pelanggaran LLAJ diatur dalam Pasal 264 sampai dengan Pasal 272 Undang-Undang Nomor 22 Tahun 2009. Penindakan pelanggaran ini dilakukan dalam bentuk pemeriksaan kendaraan bermotor di jalan yang dilakukan oleh Petugas Kepolisian Negara Republik Indonesia (selanjutnya disingkat Petugas Polri) dan Penyidik Pegawai Negeri Sipil di bidang Lalu Lintas dan Angkutan Jalan (selanjutnya disingkat PPNS LLAJ).

Penegakan hukum dalam penindakan pelanggaran LLAJ diperiksa menurut acara pemeriksaan cepat dan dapat dikenai pidana denda berdasarkan penetapan pengadilan. 
Penindakan pelanggaran di jalan dilakukan dengan menerbitkan Surat Tilang ${ }^{1}$ bagi pelanggar LLAJ.

Penindakan pelanggaran LLAJ sebagaimana didasarkan pada UndangUndang Nomor 22 Tahun 2009 dikategorikan sebagai tindak pidana ringan yang merupakan pelanggaran. Adanya Surat Tilang dan denda yang harus dibayarkan terhadap pelanggaran lalu lintas di jalan tidak serta dikategorikan sebagai tindak pidana ringan dalam ranah hukum pidana. Karakteristik tindakan pemeriksaan dan objek pemeriksaan lebih dominan berada dalam ranah hukum administrasi.

\section{B. PEMBAHASAN}

\section{Penegakan Hukum di Bidang Lalu Lintas dan Angkutan Jalan}

Penegakan hukum merupakan upaya menegakan norma hukum terhadap pelanggaran yang dilakukan. Penegakan hukum dijalankan untuk menjaga, mengawal dan menghantar hukum agar tetap tegak, searah dengan tujuan hukum dan tidak dilanggar oleh siapapun. Kegiatan penegakan hukum merupakan kegiatan penerapan hukum terhadap pelanggaran norma hukum.

Lebih lanjut hal ini dikemukakan oleh Jimly Asshiddiqie, yang menyebutkan bahwa :

"Penegakan Hukum (law enforcement) dalam arti luas mencakup kegiatan untuk melaksanakan dan menerapkan hukum serta melakukan tindakan hukum terhadap setiap pelanggaran atau penyimpangan hukum yang dilakukan oleh subjek hukum, baik melalui prosedur peradilan ataupun melalui

\footnotetext{
Tilang merupakan singkatan dari "Bukti Pelanggaran". Surat Tilang adalah catatan penyidik mengenai pelanggaran lalu lintas dan angkutan jalan tertentu yang dilakukan seseorang sebagai bukti terjadinya pelanggaran. (RPP Tata Cara Pemeriksaan Kendaraan Bermotor Di Jalan dan Penindakan Pelanggaran Lalu Lintas dan Angkutan Jalan).
}

prosedur arbitrase dan mekanisme penyelesaian sengketa lainnya (alternative desputes or conflicts resolution). Bahkan, dalam pengertian yang lebih luas lagi, kegiatan penegakan hukum mencakup pula segala aktifitas yang dimaksudkan agar hukum sebagai perangkat kaedah normatif yang mengatur dan mengikat para subjek hukum dalam segala aspek kehidupan bermasyarakat dan bernegara benar-benar ditaati dan sungguh-sungguh dijalankan sebagaimana mestinya. Dalam arti sempit, penegakan hukum itu menyangkut kegiatan penindakan terhadap setiap pelanggaran atau penyimpangan terhadap peraturan perundang-undangan, khususnya -yang lebih sempit lagi - melalui proses peradilan pidana yang melibatkan peran aparat kepolisian, kejaksaan, advokat atau pengacara, dan badan-badan peradilan".2

Penegakan hukum di bidang LLAJ meliputi penindakan pelanggaran dan penanganan Kecelakaan Lalu Lintas. Dalam hal penindakan pelanggaran, sebelumnya dilakukan pemeriksaan kendaraan bermotor di jalan. Tindakan pemeriksaan kendaraan bermotor di jalan dan penindakan pelanggaran merupakan rangkaian kegiatan penegakan hukum di bidang LLAJ. Hasil dari pelaksanaan tindakan pemeriksaan kendaraan bermotor di jalan dan ditemukan adanya pelanggaran, maka akan dilakukan tindakan penindakan pelanggaran dengan pemeriksaan acara cepat dan dikenakan tindak pidana denda.

Pemeriksaan kendaraan bermotor di jalan dilakukan oleh Petugas Polri dan PPNS LLAJ meliputi pemeriksaan :

a. Surat Izin Mengemudi (SIM), Surat Tanda Nomor Kendaraan Bermotor

2 Jimly Asshiddiqie, Pembangunan Hukum dan Penegakan Hukum di Indonesia, makalah disampaikan pada Seminar "Menyoal Moral Penegak Hukum" dalam rangka Lustrum XI Fakultas Hukum Universitas Gajah Mada, 17 Februari 2006, h. 17. 
(STNKB), Surat Tanda Coba Kendaraan Bermotor (STCKB), atau Tanda Coba Kendaraan Bermotor (TCKB);

b. tanda bukti lulus uji bagi kendaraan wajib uji;

c. fisik Kendaraan Bermotor;

d. daya angkut dan/atau cara pengangkutan barang; dan/atau

e. izin penyelenggaraan angkutan.

Wewenang pemeriksaan kendaraan bermotor di jalan oleh Petugas Polri dilakukan terhadap pemeriksaan point a sampai dengan point e, sedangkan wewenang PPNS LLAJ terhadap pemeriksaan pada point $b$ sampai dengan point e. Apabila dilihat dari wewenang pemeriksaan kendaraan bermotor di jalan, wewenang penuh berada pada Petugas Polri termasuk di dalamnya wewenang yang dimiliki oleh PPNS LLAJ.

Adanya wewenang penuh yang dimiliki oleh Petugas Polri dalam melakukan pemeriksaan kendaraan bermotor di jalan sangat kontradiksi dengan wewenang awal terkait dengan penerbitan SIM, STNKB, STCKB dan TCKB yang merupakan otoritas wewenangnya. Terkait dengan aspek tanda bukti lulus uji bagi kendaraan wajib uji, fisik kendaraan bermotor, daya angkut dan/atau cara pengangkutan barang, dan/atau izin penyelenggaraan angkutan merupakan wewenang yang dimiliki oleh PPNS LLAJ. Hal ini berarti, wewenang pemeriksaan kendaraan bermotor di jalan harus memiliki keterkaitan dengan wewenang sebelumnya dalam melakukan tindakan pemerintahan. Hal ini diperlukan agar pemeriksaan kendaraan bermotor yang dilakukan memiliki kepastian hukum. Wewenang pemeriksaan kendaraan bermotor di jalan yang dilakukan oleh Petugas Polri dan PPNS LLAJ harus didasarkan pada tugas kedinasan dalam bentuk Surat Perintah Tugas. Surat Perintah Tugas dimaksud dikeluarkan oleh Atasan Petugas Polri maupun Atasan PPNS LLAJ.

Pemeriksaan kendaraan bermotor di jalan didasarkan pada pelanggaran dan denda maksimal untuk setiap pelanggaran berdasarkan Undang-Undang Nomor 22 Tahun 2009 dapat dilihat pada tabel di bawah ini.

Tabel

Pelanggaran dan Denda Maksimal Untuk Setiap Pelanggaran

Berdasarkan Undang-Undang Nomor 22 Tahun 2009

\begin{tabular}{|c|c|c|c|}
\hline $\begin{array}{l}N \\
o\end{array}$ & Pelaku & Bentuk Pelanggaran & $\begin{array}{c}\text { Maksimal } \\
\text { Denda }(\text { Rp })\end{array}$ \\
\hline 1 & $\begin{array}{l}\text { Setiap } \\
\text { Orang }\end{array}$ & $\begin{array}{l}\text { Mengakibatkan } \\
\text { gangguan pada : fungsi } \\
\text { Rambu Lalu Lintas, } \\
\text { Marka Jalan, Alat } \\
\text { Pemberi Isyarat Lalu } \\
\text { Lintas, Fasilitas } \\
\text { Pejalan Kaki, dan alat } \\
\text { pengaman Pengguna } \\
\text { Jalan (Pasal 275 ayat } \\
\text { (2) jo Pasal } 28 \text { ayat (2)) }\end{array}$ & $250.000,00$ \\
\hline 2 & $\begin{array}{l}\text { Setiap } \\
\text { Penggu } \\
\text { na Jalan }\end{array}$ & $\begin{array}{l}\text { Tidak mematuhi } \\
\text { perintah yang diberikan } \\
\text { oleh Petugas Polri } \\
\text { sebagaimana dimaksud } \\
\text { dalam Pasal 104 ayat } \\
\text { (3), yaitu dalam } \\
\text { keadaan tertentu untuk } \\
\text { ketertiban dan } \\
\text { kelancaran lalu lintas } \\
\text { wajib untuk berhenti, } \\
\text { jalan terus, } \\
\text { mempercepat, } \\
\text { memperlambat, dan / } \\
\text { atau mengalihkan } \\
\text { kendaraan (Pasal 282 } \\
\text { jo Pasal 104 ayat (3)) }\end{array}$ & $250.000,00$ \\
\hline \multirow[t]{4}{*}{3} & $\begin{array}{l}\text { Setiap } \\
\text { Pengem } \\
\text { udi } \\
\text { (Penge } \\
\text { mudi } \\
\text { Semua } \\
\text { Jenis } \\
\text { Kendara } \\
\text { an Ber- } \\
\text { motor) } \\
\end{array}$ & $\begin{array}{l}\text { Tidak dapat } \\
\text { menunjukan SIM yang } \\
\text { sah (Pasal 288 ayat (2) } \\
\text { jo Pasal } 106 \text { ayat (5) } \\
\text { hurufb) }\end{array}$ & $250.000,00$ \\
\hline & & $\begin{array}{l}\text { Mengemudikan } \\
\text { Kendaraan Bermotor di } \\
\text { jalan, tidak memiliki } \\
\text { SIM (Pasal 281 jo } \\
\text { Pasal } 77 \text { ayat(1)) }\end{array}$ & $\begin{array}{r}1.000 .000,0 \\
0\end{array}$ \\
\hline & & $\begin{array}{l}\text { Kendaraan Bermotor } \\
\text { tidak dilengkapi dengan } \\
\text { STNK atau STCK yang } \\
\text { ditetapkan oleh Polri } \\
\text { (Pasal } 288 \text { ayat (1) jo } \\
\text { Pasal } 77 \text { ayat (1)) }\end{array}$ & $500.000,00$ \\
\hline & & $\begin{array}{l}\text { Kendaraan Bermotor } \\
\text { tidak dipasangi TNKB } \\
\text { yang ditetapkan oleh } \\
\text { Polri (Pasal 280 jo } \\
\text { Pasal 68 ayat (1)) }\end{array}$ & $500.000,00$ \\
\hline
\end{tabular}


Jemmy J. Pietersz, Karakteristik Surat Tilang.....................

\begin{tabular}{|c|c|c|c|}
\hline & & $\begin{array}{l}\text { Kendaraan Bermotor di } \\
\text { jalan dipasangi } \\
\text { perlengkapan yang } \\
\text { dapat mengganggu } \\
\text { keselamatan berlalu } \\
\text { lintas antara lain: } \\
\text { bumper tanduk dan } \\
\text { lampu menyilaukan } \\
\text { (Pasal 279 jo Pasal 58) }\end{array}$ & $500.000,00$ \\
\hline & & $\begin{array}{l}\text { Tidak mengenakan } \\
\text { sabuk } \quad \text { keselamatan } \\
(\text { Pasal } 289 \text { jo Pasal } 106 \\
\text { ayat }(6))\end{array}$ & $250.000,00$ \\
\hline & & $\begin{array}{l}\text { Tanpa menyalakan } \\
\text { lampu utama pada } \\
\text { malam hari dan kondisi } \\
\text { tertentu (Pasal } 193 \text { ayat } \\
\text { (1) jo Pasal } 107 \text { ayat } \\
\text { (1)) }\end{array}$ & $250.000,00$ \\
\hline & & $\begin{array}{l}\text { Melanggar aturan tata } \\
\text { cara penggandengan } \\
\text { dan penempelan dengan } \\
\text { kendaraan lain (Pasal } \\
287 \text { ayat (6) jo Pasal } \\
106 \text { ayat (4) huruf h) }\end{array}$ & $250.000,00$ \\
\hline & & $\begin{array}{l}\text { Mengemudi Kendaraan } \\
\text { yang tidak dilengkapi } \\
\text { dengan rumah-rumah, } \\
\text { tidak mengenakan } \\
\text { sabuk keselamatan dan } \\
\text { tidak menggunakan } \\
\text { helm (Pasal 290 jo } \\
\text { Pasal } 106 \text { ayat }(7))\end{array}$ & $250.000,00$ \\
\hline & & $\begin{array}{l}\text { Melanggar aturan } \\
\text { gerakan lalu lintas atau } \\
\text { tata cara berhenti dan } \\
\text { Parkir (Pasal } 287 \text { ayat } \\
\text { (3) jo Pasal } 106 \text { ayat } \\
\text { (4) hurufe) }\end{array}$ & $250.000,00$ \\
\hline & & $\begin{array}{l}\text { Melanggar aturan batas } \\
\text { kecepatan paling tinggi } \\
\text { atau paling rendah } \\
\text { (Pasal } 287 \text { ayat (5) jo } \\
\text { Pasal } 106 \text { ayat (4) } \\
\text { huruf g atau Pasal } 115 \\
\text { hurufa) }\end{array}$ & $500.000,00$ \\
\hline & & $\begin{array}{l}\text { Tidak memberikan } \\
\text { isyarat dengan lampu } \\
\text { penunjuk arah atau } \\
\text { isyarat tangan saat } \\
\text { akan membelok atau } \\
\text { berbalik arah (Pasal } \\
194 \text { jo Pasal } 112 \text { ayat } \\
(1))\end{array}$ & $250.000,00$ \\
\hline & & $\begin{array}{|lr|}\text { Tidak memberikan } \\
\text { isyarat saat akan } \\
\text { berpindah lajur atau } \\
\text { bergerak ke samping } \\
\text { (Pasal 295 jo Pasal 112 } \\
\text { ayat (2)) }\end{array}$ & $250.000,00$ \\
\hline & & \begin{tabular}{|lr} 
Melanggar aturan \\
perintah & atau larangan \\
yang & dinyatakan \\
dengan & Rambu Lalu \\
Lintas atau Marka \\
(Pasal 287 ayat (1) jo
\end{tabular} & $500.000,00$ \\
\hline
\end{tabular}

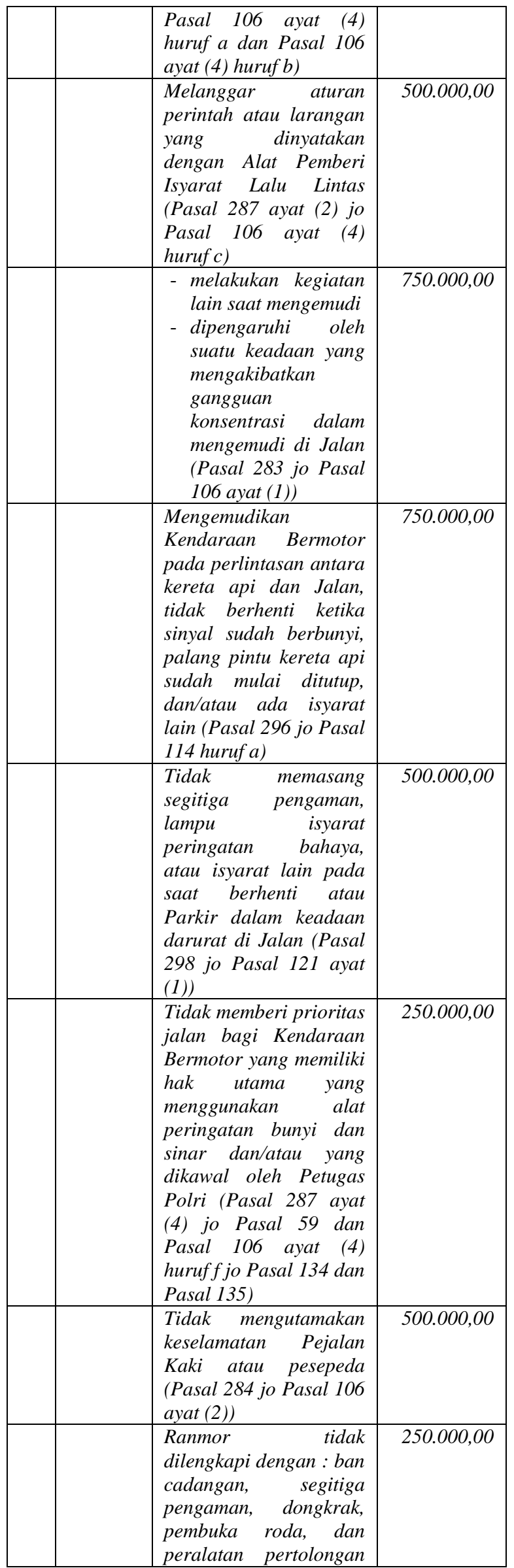


Jemmy J. Pietersz, Karakteristik Surat Tilang.....................

Jurnal Sasi Vol. 16 No. 3 Bulan Juli-September 2010

\begin{tabular}{|c|c|c|c|}
\hline & & $\begin{array}{l}\text { pertama pada } \\
\text { kecelakaan }(\text { Pasal } 278 \\
\text { jo Pasal } 57 \text { ayat (3)) }\end{array}$ & \\
\hline & & $\begin{array}{l}\text { Pengmudi atau } \\
\text { penumpang yang duduk } \\
\text { di samping pengemudi } \\
\text { tidak mengenakan } \\
\text { sabuk keselamatan } \\
\text { (Pasal 289 jo Pasal 106 } \\
\text { ayat (6)) }\end{array}$ & $250.000,00$ \\
\hline & & $\begin{array}{lr}\text { Pengemudi } & \text { dan } \\
\text { Penumpang } & \text { tidak } \\
\text { mengenakan } & \text { sabuk } \\
\text { keselamatan dan } & \text { helm } \\
\text { (Pasal 290 jo Pasal 106 } \\
\text { ayat (7)) }\end{array}$ & $250.000,00$ \\
\hline & & $\begin{array}{l}\text { Ranmor } r \text { tidak } \\
\text { memenuhi persyaratan } \\
\text { teknis meliputi: kaca } \\
\text { spion, klakson, lampu } \\
\text { utama, lampu mundur, } \\
\text { lampu tanda batas } \\
\text { dimensi badan } \\
\text { kendaraan, lampu } \\
\text { gandengan, lampu rem, } \\
\text { lampu penunjuk arah, } \\
\text { alat pemantul cahaya, } \\
\text { alat pengukur } \\
\text { kecepatan, kedalaman } \\
\text { alur ban, kaca depan, } \\
\text { spakbor, bumper, } \\
\text { penggandengan, } \\
\text { penempelan, atau } \\
\text { penghapus kaca (Pasal } \\
\text { 285 ayat (2) jo Pasal } \\
\text { l06 ayat (3) jo Pasal } 48 \\
\text { ayat (2)) }\end{array}$ & $500.000,00$ \\
\hline & & $\begin{array}{l}\begin{array}{l}\text { Kendaraan } \\
\text { tidak }\end{array} \\
\begin{array}{l}\text { Bermotor } \\
\text { persyaratan }\end{array} \\
\text { persik jalan } \\
\text { (Pasal 286 jo Pasal } 106 \\
\begin{array}{l}\text { ayat (3) jo Pasal } 48 \\
\text { ayat (3)) }\end{array} \\
\end{array}$ & $500.000,00$ \\
\hline 5 & $\begin{array}{l}\text { Penum- } \\
\text { pang } \\
\text { Kendara } \\
\text { an Ber- } \\
\text { motor } \\
\text { Yang } \\
\text { Duduk } \\
\text { Di Sam- } \\
\text { ping } \\
\text { Peng- } \\
\text { emudi }\end{array}$ & $\begin{array}{l}\text { Tidak mengenakan } \\
\text { sabuk } \quad \text { keselamatan } \\
\text { (Pasal 289 jo Pasal } 106 \\
\text { ayat (6)) }\end{array}$ & $250.000,00$ \\
\hline 6 & $\begin{array}{l}\text { Peng- } \\
\text { emudi } \\
\text { Kendara } \\
\text { an Ber- } \\
\text { motor } \\
\text { Umum } \\
\text { Ang- } \\
\text { kutan } \\
\text { Orang }\end{array}$ & $\begin{array}{l}\text { Kendaraan Bermotor } \\
\text { tidak dilengkapi dengan } \\
\text { Surat Keterangan Uji } \\
\text { Berkala (Pasal } 288 \text { ayat } \\
\text { (3) jo Pasal } 106 \text { ayat } \\
\text { (5) hurufc }\end{array}$ & $500.000,00$ \\
\hline & & 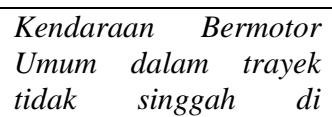 & $250.000,00$ \\
\hline
\end{tabular}

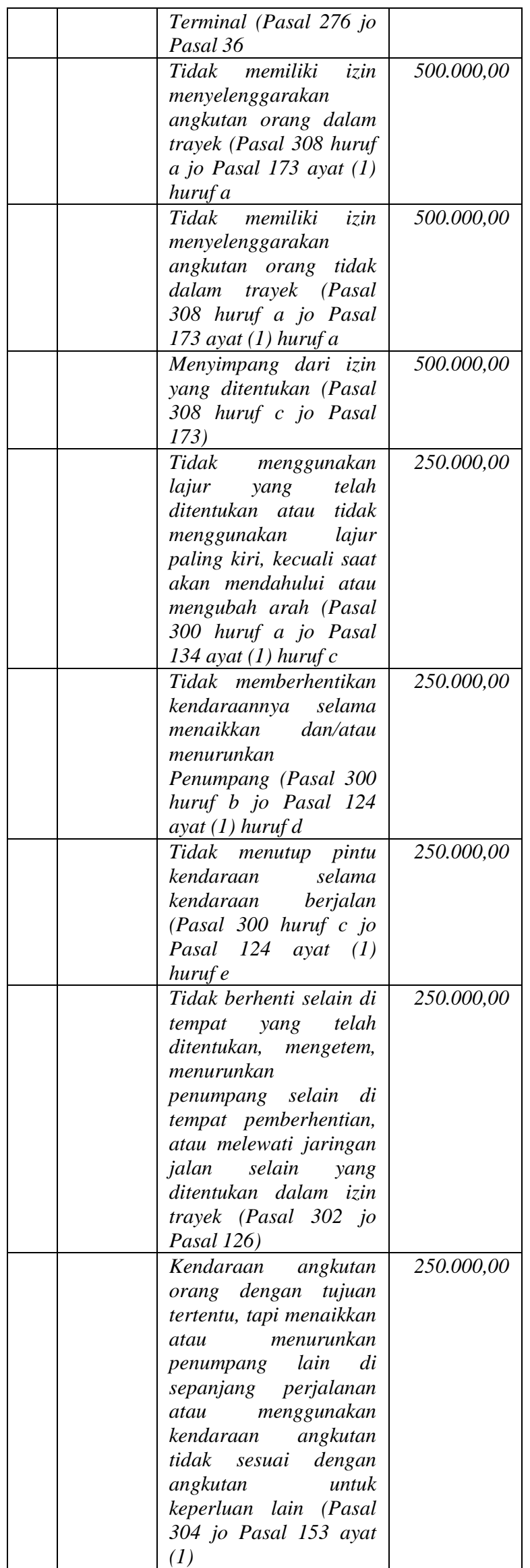


Jemmy J. Pietersz, Karakteristik Surat Tilang....................

\begin{tabular}{|c|c|c|c|}
\hline 7 & $\begin{array}{l}\text { Peng- } \\
\text { emudi } \\
\text { Bus }\end{array}$ & $\begin{array}{lr}\text { Kendaraan } & \text { Bermotor } \\
\text { Bus tidak dilengkapi } \\
\text { dengan } \\
\text { keterangan uji berkala } \\
\text { dan tanda lulus uji } \\
\text { berkala (Pasal } 288 \text { ayat } \\
\text { (3) jo Pasal } 106 \text { ayat } \\
\text { (5) huruf c) }\end{array}$ & $500.000,00$ \\
\hline \multirow[t]{4}{*}{8} & $\begin{array}{l}\text { Peng- } \\
\text { emudi } \\
\text { Ang- } \\
\text { kutan } \\
\text { Barang }\end{array}$ & $\begin{array}{l}\text { Kendaraan } \text { Bermotor } \\
\text { dan/atau } \quad \text { Kereta } \\
\text { Gandengannya atau } \\
\text { Kereta Tempelannya } \\
\text { tidak dilengkapi dengan } \\
\text { surat keterangan uji } \\
\text { berkala dan tanda lulus } \\
\text { uji berkala (Pasal } 288 \\
\text { ayat (3) jo Pasal } 106 \\
\text { ayat (5) hurufc) }\end{array}$ & $500.000,00$ \\
\hline & & $\begin{array}{l}\text { Tidak menggunakan } \\
\text { jaringan jalan sesuai } \\
\text { dengan kelas jalan yang } \\
\text { ditentukan (Pasal } 301 \\
\text { jo Pasal 125) }\end{array}$ & $250.000,00$ \\
\hline & & $\begin{array}{l}\text { Mobil barang untuk } \\
\text { mengangkut } \\
\text { tanpa alasan (Pasal } 303 \\
\text { jo Pasal } 137 \text { ayat (4) } \\
\text { hurufa, b, dan c) }\end{array}$ & $250.000,00$ \\
\hline & & $\begin{array}{l}\text { Membawa muatan, } \\
\text { tidak dilengkapi surat } \\
\text { muatan dokumen } \\
\text { perjalanan (Pasal } 306 \\
\text { jo Pasal 168 ayat (1) }\end{array}$ & $250.000,00$ \\
\hline \multirow[t]{2}{*}{9} & $\begin{array}{l}\text { Peng- } \\
\text { emudi } \\
\text { Angkuta } \\
\text { n Umum } \\
\text { Barang }\end{array}$ & $\begin{array}{l}\text { Tidak mematuhi } \\
\text { ketentuan mengenai } \\
\text { tata cara pemuatan, } \\
\text { daya angkut, dimensi } \\
\text { kendaraan (Pasal } 307 \\
\text { jo Pasal 169 ayat (1)) }\end{array}$ & $500.000,00$ \\
\hline & & 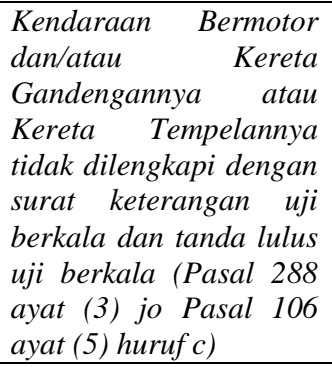 & $500.000,00$ \\
\hline 10 & $\begin{array}{l}\text { Pengem } \\
\text { udi } \\
\text { Yang } \\
\text { Mengan } \\
\text { gkut } \\
\text { Barang } \\
\text { Khusus } \\
\text { (Persyar } \\
\text { atan } \\
\text { Keselam } \\
\text { atan } \\
\text { dan } \\
\text { Keaman } \\
\text { an) } \\
\end{array}$ & $\begin{array}{l}\text { Tidak memenuhi } \\
\text { ketentuan persyaratan } \\
\text { keselamatan, pemberian } \\
\text { tanda barang, Parkir, } \\
\text { bongkar dan muat, } \\
\text { waktu operasi dan } \\
\text { rekomendasi dari } \\
\text { instansi terkait (Pasal } \\
305 \text { jo Pasal 162 ayat } \\
\begin{array}{l}\text { (1) huruf a, b, c, d, dan } \\
\text { e atauf) }\end{array}\end{array}$ & $500.000,00$ \\
\hline 11 & $\begin{array}{l}\text { Pengend } \\
\text { ara } \\
\text { Sepeda }\end{array}$ & $\begin{array}{l}\text { Tanpa menyalakan } \\
\text { lampu utama pada } \\
\text { siang hari (Pasal } 293\end{array}$ & $100.000,00$ \\
\hline
\end{tabular}

\begin{tabular}{|c|c|c|c|}
\hline & Motor & $\begin{array}{l}\text { ayat (2) jo Pasal } 107 \\
\text { ayat (2)) }\end{array}$ & \\
\hline & & \begin{tabular}{lll} 
Tidak & \multicolumn{2}{c}{ mengenakan } \\
Helm SNI (Pasal 291 \\
ayat (2) jo Pasal 106 \\
ayat (8))
\end{tabular} & $250.000,00$ \\
\hline & & $\begin{array}{l}\text { Membiarkan } \\
\text { penumpangnya tidak } \\
\text { mengenakan Helm } \\
\text { (Pasal } 291 \text { ayat (2) jo } \\
\text { Pasal 106 ayat (8) } \\
\end{array}$ & $250.000,00$ \\
\hline & & $\begin{array}{l}\text { Tanpa kereta samping } \\
\text { mengangkut penumpang } \\
\text { lebih dari } 1 \text { (satu) } \\
\text { orang (Pasal } 292 \text { jo } \\
\text { Pasal 106 ayat (9)) }\end{array}$ & $250.000,00$ \\
\hline & & $\begin{array}{l}\text { Tidak memenuhi } \\
\text { persyaratan teknis dan } \\
\text { laik jalan (Pasal } 285 \\
\text { ayat (1) jo Pasal } 106 \\
\text { ayat (3), dan Pasal } 48 \\
\text { ayat (2), dan ayat (3)) }\end{array}$ & $250.000,00$ \\
\hline 12 & $\begin{array}{l}\text { Peng- } \\
\text { endara } \\
\text { Ken- } \\
\text { daraan } \\
\text { Tidak } \\
\text { Be- } \\
\text { rmotor }\end{array}$ & $\begin{array}{l}\text { Dengan sengaja: } \\
\text { - berpegang pada } \\
\text { Kendaraan } \\
\text { Bermotor untuk } \\
\text { ditarik } \\
\text { - menarik benda- } \\
\text { benda yang dapat } \\
\text { membahayakan } \\
\text { Pengguna Jalan } \\
\text { lain, dan/atau } \\
\text { - menggunakan jalur } \\
\text { jalan kendaraan } \\
\text { bermotor, sedang } \\
\text { telah disediakan } \\
\text { jalur jalan khusus } \\
\text { bagi Kendaraan } \\
\text { Tidak Bermotor } \\
\text { (Pasal 299 jo Pasal } \\
\text { 122 huruf a, b, dan } \\
\text { c) }\end{array}$ & $100.000,00$ \\
\hline
\end{tabular}

\section{Penerbitan Surat Tilang}

Penindakan pelanggaran LLAJ didasarkan atas hasil temuan dalam proses pemeriksaan kendaraan bermotor di jalan, hasil laporan, dan hasil rekaman peralatan elektronik. Penindakan pelanggaran LLAJ dilakukan dengan menerbitkan Surat Tilang dengan pengisian dan penandatanganan Blanko Tilang. Blanko Tilang sekurangkurangnya berisi kolom tentang (a) identitas pelanggar dan kendaraan bermotor yang digunakan; (b) ketentuan dan pasal yang dilanggar; (c) hari, tanggal, jam dan tempat terjadinya pelanggaran; (d) barang bukti yang disita; (e) jumlah uang titipan denda; (f) tempat atau alamat dan/atau nomor 
telpon pelanggar; (g) pemberian kuasa; (h) penandatangan oleh pelanggar dan petugas pemeriksa; (i) berita acara singkat penyerahan surat tilang kepada pengadilan; (j) hari, tanggal, jam dan tempat untuk menghadiri sidang pengadilan; dan (k) catatan petugas penindak.

Surat Tilang harus ditandatangani oleh Petugas Pemeriksa dan pelanggar. Dalam hal pelanggar tidak bersedia menandatangani Surat Tilang, maka Petugas Pemeriksa harus memberikan catatan. Surat Tilang ini akan digunakan untuk kepentingan pelanggar sebagai dasar hadir di persidangan atau pembayaran uang titipan, Kepolisian Negara Republik Indonesia, Pengadilan Negeri setempat, Kejaksaan Negeri setempat dan Instansi yang membawahi PPNS yang bersangkutan.

Surat Tilang dan alat bukti disampaikan kepada Pengadilan Negeri tempat terjadinya pelanggaran dalam waktu paling lama 14 (empat belas) hari sejak terjadinya pelanggaran. Dalam hal pelanggar menitipkan uang denda melalui bank yang ditunjuk oleh pemerintah, bukti penitipan uang denda dilampirkan dalam Surat Tilang. Pelaksanaan persidangan pelanggaran LLAJ dilaksanakan sesuai dengan hari sidang yang tersebut dalam Surat Tilang. Persidangan ini dilaksanakan dengan atau tanpa kehadiran pelanggar atau kuasanya. Apabila pelanggar tidak menitipkan uang denda titipan atau tidak memenuhi amar putusan pengadilan dalam jangka waktu selama 14 (empat belas) hari sejak putusan dijatuhkan, petugas mengajukan pemblokiran Surat Tanda Nomor Kendaraan Bermotor (STNKB).

\section{Karakteristik Sanksi Administrasi Surat Tilang}

Beranjak dari penegakan hukum di bidang LLAJ termasuk penerbitan Surat Tilang sebagai bentuk penindakan pelanggaran dan uang denda berdasarkan putusan pengadilan sebagaimana dikemukakan di atas, merupakan konsep penegakan hukum dalam ranah hukum pidana sebagaimana diatur dalam UndangUndang Nomor 22 Tahun 2009. Upaya penegakan hukum yang dilakukan oleh Petugas Polri maupun PPNS LLAJ lebih memperjelas tindakan dimaksud sebagai instrumen hukum pidana yang diawali dengan proses penyelidikan. Hal ini tentunya menimbulkan permasalahan hakekat dan karakter hukum terkait dengan tindakan pemerintahan di bidang LLAJ.

Penegakan hukum dalam ranah hukum administrasi dilakukan terkait dengan upaya memaksakan kepatuhan dari warga masyarakat terhadap kewajiban atau larangan yang diatur dalam peraturan perundang-undangan. Menurut Philipus M. Hadjon, menyatakan bahwa :

"Pada umumnya tidak ada gunanya memasukkan kewajiban-kewajiban atau larangan-larangan bagi para warga di dalam peraturan perundang-undangan tata usaha negara, manakala aturanaturan tingkah laku itu tidak dapat dipaksakan oleh tata usaha negara (dalam hal dimaksud diperlukan). Bagi pembuat peraturan penting untuk tidak hanya melarang tindakan-tindakan yang tanpa disertai izin, tetapi juga terhadap tindakan-tindakan yang bertentangan dengan peraturan perundang-undangan yang dapat dikaitkan pada suatu izin. ${ }^{3}$

Agar kewajiban-kewajiban atau larangan-larangan tersebut efektif, pejabat administrasi harus diberi kemampuan yang bersifat memaksa untuk menegakkan kewajiban atau larangan dimaksud. Philipus M. Hadjon menyatakan bahwa instrumen penegakan hukum administras meliputi pengawasan dan penegakan sanksi. Pengawasan merupakan upaya preventif untuk memaksakan kepatuhan, sedangkan

Philipus M. Hadjon (Philipus M. Hadjon I), Discretionary Power dan Asas-Asas Umum Pemerintahan Yang Baik (AAUPB), Paper, disampaikan pada Seminar Nasional "Aspek Pertanggungjawaban Pidana Dalam Kebijakan Publik Dari Tindak Pidana Korupsi", Semarang, 6-7 Mei 2004, h. 245. 
penerapan sanksi merupakan upaya represif untuk memaksakan kepatuhan. ${ }^{4}$

Unsur-unsur pokok dari penegakan hukum administrasi dikemukakan pula oleh Tatiek Sri Djatmiati yang menyatakan bahwa:

"Penegakan hukum di bidang hukum administrasi mempunyai dua unsur pokok yaitu:

1) Pengawasan;

2) Sanksi.

Pengawasan dilakukan terhadap kepatuhan warga masyarakat, agar ketentuan yang bersifat mewajibkan, atau ketentuan yang dilarang tidak dilanggar. Dengan demikian sanksi pada hakikatnya merupakan instrumen yuridis yang biasanya diberikan apabila kewajiban-kewajiban atau laranganlarangan yang ada dalam ketentuan hukum telah dilanggar."

Konsep penegakan hukum administrasi berupa pengawasan dan penerapan sanksi sebagaimana dikemukakan di atas, secara jelas merupakan konsep pengaturan dalam Undang-Undang Nomor 22 Tahun 2009. Namun pengaturan dalam Undang-Undang Nomor 22 Tahun 2009 lebih dominan mengarahkan tindakantindakan pemerintahan dimaksud dalam ranah hukum pidana.

Apabila dikaitkan dengan penyelenggaraan LLAJ, Undang-Undang Nomor 22 Tahun 2009 dimaksudkan untuk menekan angka Kecelakaan Lalu Lintas yang dirasakan sangat tinggi, dan diarahkan upaya penanggulangan secara komprehensif yang mencakup upaya pembinaan, pencegahan, pengaturan dan penegakan

4 Philipus M. Hadjon (Philipus M. Hadjon II), Penegakan Hukum Administrasi Dalam Pengelolaan Lingkungan Hidup, dalam B. Arief Sidarta, et., al., (Editors), Butir-butir Gagasan tentang Penyelenggaraan Hukum dan Pemerintahan yang Layak, Citra Aditya Bakti, Bandung, 1996, h. 337.

${ }^{5}$ Tatiek Sri Djatmiati, Prinsip Izin Usaha Industri Di Indonesia, Disertasi, Program Pascasarjana Universitas Airlangga, Surabaya, 2004, h. 82 hukum. Upaya pembinaan dilakukan melalui peningkatan intensitas pendidikan lalu lintas dan penyuluhan hukum serta pembinaa sumber daya manusia. Untuk upaya pencegahan dilakukan melalui peningkatan pengawasan kelaikan jalan, sarana dan prasanara, serta kelaikan kendaraan, termasuk pengawasan di bidang LLAJ yang lebih intensif. Upaya pengaturan meliputi Manajemen dan Rekayasa Lalu Lintas dan modernisasi sarana dan prasarana Lalu Lintas. Upaya penegakan hukum dilaksanakan lebih efektif melalui perumusan ketentuan hukum yang jelas serta penerapan sanksi yang lebih tegas.

Penyelenggaraan LLAJ yang merupakan latar belakang Undang-Undang Nomor 22 Tahun 2009 seyogyanya lebih dominan diarahkan dalam ranah hukum administrasi terkait dengan penegakan hukum administrasi berupa pengawasan dan penerapan sanksi. Hal ini dalam UndangUndang Nomor 22 Tahun 2009 bentuk pengawasan berupa pemeriksaan kendaraan bermotor di jalan dilakukan secara berkala dan insidentil. Padahal pengawasan dalam hukum administrasi merupakan rutinitas tugas pemerintahan dalam konsep besturen (bestuur).

Pengawasan merupakan tindakan preventif pemerintah untuk memaksakan kepatuhan terhadap kewajiban-kewajiban dan larangan-larangan sebelum sampai pada pengenaan sanksi atas pelanggaran dimaksud. Lebih lanjut Philipus M. Hadjon menyatakan bahwa :

"Pengenaan sanksi-sanksi hanya mungkin apabila badan tata usaha negara mengetahui adanya pelanggaranpelanggaran nyata atas peraturan perundang-undangan. Hal itu tidak terjadi dengan sendirinya. Karena itu tata usaha negara memperkerjakan pegawai-pegawai yang ditugaskan untuk mengadakan pengawasan (disebut juga: kontrol). ....

Pengawasan sebagaimana dimaksud di atas, di dalam praktek merupakan syarat bagi dimungkinkannya pengenaan sanksi. Sekaligus menurut pengalaman, 
pelaksanaan dari pengawasan itu sendiri telah mendukung penegakan hukum (hukum administrasidhaving). ... Lagi pula pegawai-pegawai pengawasan melalui penerangan (penyuluhan), anjuran (bujukan), peringatan dan nasehal biasanya dapat mencegah terjadinya suatu keadaan pengenaan sanksi ....

Bagi pengadaan pengawasan atau kontrol itu sendiri tidak perlu terdapat dugaan terjadinya suatu perbuatan pidana. $^{6}$

\section{Lebih lanjut Siti Sundari Rangkuti} mengemukakan bahwa :

"Penegakan hukum yang bersifat preventif berarti bahwa pengawasan aktif dilakukan terhadap kepatuhan kepada peraturan tanpa kejadian langsung yang menyangkut peristiwa konkret yang menimbulkan sangkaan bahwa peraturan hukum telah dilanggar. Instrumen bagi preventif adalah penyuluhan, pemantauan, dan penggunaan kewenangan yang sifatnya pengawasan .... Dengan demikian penegak hukum yang utama adalah pejabat/aparat pemerintah yang berwenang memberi izin ....",

Pemeriksaan kendaraan bermotor di jalan telah dikemukakan sebelumnya memiliki keterkaitan dengan tindakan pemerintah dalam melaksanakan fungsi pengendalian (sturen). Tentunya tindakan pemerintah dalam melakukan pemeriksaan yang merupakan bentuk pengawasan seyogyanya terkait pula dengan tindakan pemerintah yang dilakukan sebelumnya. Tindakan pemeriksaan kendaraan bermotor di jalan yang meliputi pemeriksaan SIM, STNKB, STCKB, TNKB, TCKB, tanda lulus uji bagi kendaraan wajib uji, fisik kendaraan bermotor, daya angkut dan/atau

\footnotetext{
${ }^{6}$ Philipus M. Hadjon I, Op. Cit., h. 248

${ }^{7}$ Siti Sundari Rangkuti, Hukum Lingkungan dan Kebijaksanaan Lingkungan Nasional, Airlangga University Press, Surabaya, 2000, h. 209-210.
}

cara pengangkutan barang, dan/atau izin penyelenggaraan angkutan merupakan bentuk tindakan administratif yang dilakukan oleh pemerintah. Karakteristik tindakan pemerintah ini merupakan bentuk perizinan untuk mengendalikan warga masyarakat di bidang LLAJ. Dengan demikian, penegakan hukum terhadap tindakan pemerintah dimaksud harus dilakukan dalam bentuk penegakan hukum administrasi.

Surat Tilang sebagai bentuk penindakan pelanggaran dari hasil pemeriksaan kendaraan bermotor di jalan dalam ranah hukum administrasi pada hakekatnya merupakan tindakan paksaan pemerintahan (bestuurdwang) ${ }^{8}$. Terkait dengan paksaan pemerintahan (bestuurdwang), Philipus M. Hadjon mengemukakan bahwa: ${ }^{9}$

... wewenang penerapan sanksi berupa paksaan pemerintahan adalah wewenang diskresi. Hakikat wewenang penerapan sanksi paksa pemerintahan sebagai wewenang diskresi sudah merupakan doktrin hukum administrasi. Dalam penerapan wewenang diskresi haruslah dipertimbangkan secara rasional, apakah wewenang tersebut digunakan atau tidak.

Kalau dibandingkan dengan AWB, dalam artikel 5:21 dirumuskan pengertian atau konsep bestuursdwang yang esensinya adalah: tindakan nyata, dapat dilakukan oleh pemerintah sendiri ataupun dengan menunjuk pihak ketiga yang bertindak atas nama pemerintah.

\footnotetext{
${ }^{8}$ Paksaan pemerintahan (bestuursdwang) merupakan tindakan-tindakan yang nyata (feitelijke handeling) dari penguasa dengan cara langsung guna mengakhiri suatu keadaan yang dilarang oleh suatu kaedah hukum administrasi.

9 Philipus M. Hadjon (Philipus M. Hadjon III), Mekanisme Paksaan Pemerintah (bestuursdwang) dan Uang Paksa (dwangsom) sebagai Sanksi Utama Penegakan Hukum Lingkungan, Makalah pada Seminar Nasional Hukum Lingkungan, di Fakultas Hukum UNAIR pada tanggal 16 Juli 2005, h. 2-3.
} 
Kewenangan memberikan izin bagi warga masyarakat dalam menyelenggarakan tindakan tertentu di bidang LLAJ harus koheren dengan pengawasan dan penegakan sanksi administrasi. Karakteristik Surat Tilang sebagai tindakan pengenaan sanksi dengan pencantuman denda administratif berdasarkan jenis pelanggaran dan besarnya denda merupakan tindakan sepihak dari pemerintah dan tidak memerlukan adanya putusan pengadilan. Surat Tilang merupakan pemaksanaan terhadap pelanggaran yang secara sepihak dilakukan oleh aparatur pemerintahan. ${ }^{10}$

Bentuk Surat Tilang dalam penindakan pelanggaran dikategorikan sebagai Keputusan Tata Usaha Negara yang bersifat pembebanan. Blangko Tilang yang merupakan tindakan sepihak dalam penerapan sanksi administrasi tanpa adanya persetujuan dari pelanggar. Tentunya berdasarkan wewenang penindakan dan diskresi yang dimiliki, aparatur pemerintah dapat menjatuhkan hukuman dengan Surat Tilang sebagai Keputusan Tata Usaha Negara tanpa melalui putusan pengadilan. Apabila tindakan pemerintah dalam menjatuhkan sanksi berupa Surat Tilang tidak sesuai dengan kenyataan dalam penindakan pelanggaran, maka pelanggar dapat menempuh upaya hukum untuk memperoleh perlindungan hukum melalui upaya administratif dengan mengajukan keberatan, atau melalui Komisi Ombudsman Nasional terhadap tindakan malpraktek aparatur pemerintahan, serta Pengadilan Tata Usaha Negara.

10 Dalam pendekatan aparatur pemerintahan, Kepolisian Negara Republik Indonesia merupakan aparatur pemerintahan yang melakukan fungsi penyelenggaraan pemerintahan berdasarkan Undang-Undang Nomor 2 Tahun 2002 tentang Kepolisian Negara Republik Indonesia.

\section{PE N T U P}

Berdasarkan analisis sebagaimana dikemukakan di atas, penyelenggaraan LLAJ merupakan tindakan pemerintahan dalam ranah hukum administrasi. Adanya penindakan pelanggaran dalam bentuk Surat Tilang terhadap hasil pemeriksaan kendaraan bermotor di jalan merupakan bentuk penegakan sanksi administrasi. Apalagi karakteristik Surat Tilang merupakan Keputusan Tata Usaha Negara.

\section{DAFTAR PUSTAKA}

Asshiddiqie, Jimly, Pembangunan Hukum dan Penegakan Hukum di Indonesia, makalah disampaikan pada Seminar "Menyoal Moral Penegak Hukum" dalam rangka Lustrum XI Fakultas Hukum Universitas Gajah Mada, 17 Februari 2006.

Hadjon, Philipus M., Discretionary Power dan Asas-Asas Umum Pemerintahan Yang Baik (AAUPB), Paper, disampaikan pada Seminar Nasional "Aspek Pertanggungjawaban Pidana Dalam Kebijakan Publik Dari Tindak Pidana Korupsi", Semarang, 6-7 Mei 2004.

\section{Pemerintah}

(bestuursdwang) dan Uang

Paksa (dwangsom) sebagai

Sanksi Utama Penegakan 


\section{Hukum Lingkungan,}

Makalah pada Seminar

Nasional Hukum

Lingkungan, di Fakultas

Hukum UNAIR pada tanggal

16 Juli 2005.

Rangkuti, Siti Sundari, 2000, Hukum

Lingkungan dan

Kebijaksanaan Lingkungan

Nasional, Airlangga

University Press, Surabaya.

Shidarta, B. Arief, et., al., (Editors), 1996,

Butir-butir

Gagasan

tentang Penyelenggaraan

Hukum dan Pemerintahan yang Layak, Citra Aditya

Bakti, Bandung.

Sri Djatmiati, Tatiek, Prinsip Izin Usaha Industri Di Indonesia, Disertasi, Program Pascasarjana Universitas Airlangga, Surabaya, 2004.

Undang-Undang Nomor 22 Tahun 2009 tentang Lalu Lintas dan Angkutan Jalan

Rancangan Peraturan Pemerintah tentang Tata Cara Pemeriksaan Kendaraan Bermotor di Jalan dan Penindakan Pelanggaran Lalu Lintas dan Angkutan Jalan. 